\title{
MARKET ANALYSIS OF HOTEL SERVICES IN UKRAINE
}

\author{
Iryna ANTONOVA', \\ East European University of Economics and Management, Ukraine
}

\begin{abstract}
The subject of this research is the market of hotel services in Ukraine in recent years, since the market for the hotel services in Ukraine emerged in the first half of the 2000s. Initially, the focus of both local and foreign investors was on the development of the hotel market in Kyiv. Gradually, with the development of hotel business in Ukraine, investors' interest began to shift in the direction of populated cities, primarily large business centers of the country (with a population of about 1 million people) such as Kharkiv, Donetsk, Dnipropetrovsk, Lviv and in the direction of resort areas - Crimea, Carpathians, Odessa. According to the World Tourism Organization during the past 24 years the income from international tourism has increased by $9 \%$. The number of international tourists every year is growing at a rate of $4 \%$. Active development of hotel real estate segment was highly influenced by the European football championship held in 2011 due to the requirements of the cities-organizers which hosted matches (Kyiv, Kharkiv, Donetsk, Lviv) to have certain number of hotel rooms of different categories.
\end{abstract}

Purpose. The study is an analysis of the problems in the market of hotel services and prospects for their solution. Hospitality industry in Ukraine is one of the fastest growing sectors of the economy. It is pleasant to note that new hotels, rest houses and resorts are being opened while the existing hotels are being reconstructed to meet higher levels of services. Unsaturated market of hotel services of different levels creates a great opportunity for international hotel operators to enter Ukrainian market with confidence and expand its influence in the industry by the means of its internal policies. Therefore, this study is very relevant in the modern realms.

The methodological base of research were works of domestic and foreign authors dedicated to the problems of the hotel industry development. Existing problems in the hospitality industry:

1. Tendency toward market being filled with foreign companies

2. At the present stage of economic development in Ukraine there are only two national hotel operator - Premier Hotels and Resorts and Reikartz Hotels \& Resorts.

3. Market of hotel services in Ukraine is now approaching saturation in the sector of five-and four-star hotels.

4. The formation of situation explained above leads to the gradual saturation of high-end hotel market as well as increase in the number of foreign companies in the market. As a result some companies have to work together and develop a common business strategy.

5. Sector of hotels of three stars and below remains unsaturated and represented mainly by the hotels with extremely low-maintenance and a small set of services.

6. There is no significant improvement in the activity level in the sector of hotel services in Ukraine, with Ukrainian companies delaying their market entrance. This can lead to the market being filled by the foreign hotel chains. At the same time western investors do not want to start their business in Ukraine without active presence of Ukrainian companies.

7. Due to the nature of specific markets it is impossible to provide adequate assessment of the situation in the industry. It is necessary to view different sectors of hotel services separately.

8. The problem of effective management remains important to national hotels. The shift from administrative methods of management to market methods was not easy and oftentimes managerial team that was supposed to maintain high levels of performance works on development. This shortcoming has also to deal with the founders/ owners of the hotels.

9. The issues related to the interaction with the government still remain problematic for the national hotel chains. Those issues include the process of hotel registration, plot allotment for the hotel construction, mandatory procedures in the fire and health departments, as well as obtaining of the necessary permits and certificates.

10. The issue of standardization is also problematic because of inconsistencies between Ukrainian and European

\footnotetext{
Corresponding author

${ }^{I}$ Department of Marketing, East European University of Economics and Management.

E-mail: antonova_ira@ukr.net
} 
systems of standardization of hotel services. It is estimated that $80 \%$ of hospitality real estate including hotels, in need of repair and reconstruction.

These ambiguous situations complicate and slow down the activities of the companies in the hotel sphere. Yet, national hotel operators have an advantage being aware of existence of such matters and having knowledge of national legislation.

Conclusion. Despite the difficult political and economic conditions emergence of new national hotel operator in Ukraine is not a utopia, moreover, such attempts are made today. In the sector of hotel services of the highest category national operators face stiff competition, not only price based but also competition based on quality. To win such competition while maintaining individual brand is possible only by maintaining faultless management and marketing. Emergence of national hotel operator is most likely in the sector of middle-class hotel services because this segment is unsaturated and also very promising. Hotel facilities in this case will be based mainly in the regional centers and will be unionized by the single concept. In any case, the development of Ukrainian hotel operators will mean a transition to a new level in the framework of the global market of hotel services. If before Ukraine was only described as undeveloped and unsaturated new market, the creation of a national network will create a new player in the global hotel market.

Key words: hotel, market, economics, marketing, market research, stardom, infrastructure, tourism.

JEL Classification: L15, L21, L83, M10

\section{Introduction}

Formation of the hotel services in Ukraine began in the first half of the 2000s. Initially, the focus of both local and foreign investors was on the development of the hotel market in Kyiv. Gradually, with the development of hotel business in Ukraine, investors' interest began to shift in the direction of regional cities, primarily large business centers of the country (with a population of about 1 million People) such as Kharkiv, Donetsk, Dnipropetrovsk, Kharkiv, Lviv and resort areas such as Crimea, Carpathians, Odessa.

Active development of hotel real estate segment was highly influenced by the European football championship held in 2011 due to the requirements of the citiesorganizers which hosted matches (Kyiv, Kharkiv, Donetsk, Lviv) to have certain number of hotel rooms of different categories.

Hotel services sector remains one of the most dynamic sectors of Ukraine's economy. Unsaturated market of hotel services of different levels creates a great opportunity for international hotel operators to enter Ukrainian market with confidence and expand its influence in the industry by the means of its internal policies. Therefore, this study is very relevant in the modern realms.

\section{Problems market}

To problematic points in the functioning of the hotel services in Ukraine include (Gorin, 2009):

1. Tendency toward market being filled with foreign companies. To answer with confidence whether this trend is confirmed in future and whether there is a potential for the development of national hotel operators in Ukraine, one should conduct a thorough analysis of the market actions and situations that may lead to the development of national hotel chains.

2. At the present stage of economic development in Ukraine there are two national hotel operators which are Premier Hotels and Resorts and Reikartz Hotels \&
Resorts. The first national network of Premier Hotels and Resorts hotels includes seventeen 5 to 3 stars hotels, different on their own but equally welcoming and cozy. Hotels were established not in accordance with conventional strategies, since they form a union of hotels with different concept strategies and range of services offered in major business and tourist centers of Ukraine. Due to the specifics of each individual hotel network does not have to solve the problems associated with the uniformity of the product. This kind of association allows you to double the competitive advantage associated with market positioning and brand awareness, as well as benefit from a single hotel reservation systems. It is difficult to identify PremiereHotels hotel operator as one hotel network due to the hotels' positioning in different segments and under different trademarks. Hotels Reikartz Hotels \& Resorts are located in major cities and attractive resorts of Ukraine. Each hotel of the network is distinguished by the high level of comfort and service, strict compliance with European standards of service as well as warm and attentive treatment of the guests. The history of the Reikartz Company in Ukraine began in 2003, when a group of Belgian architects led by François Reikartz (Francois Ryckaerts) acquired an old mansion in the city center of Lviv on Drukarska Street. Partners noted that hotels of European level 3 and 4 stars were virtually absent in Ukraine so they decided to create a Ukrainian hotel chain under the brand Reikartz Hotels \& Resorts. François Reikartz attracted a group of investors to work on the project and joined the board of Reikartz Hotel Management as the chief architect of the project.

The first hotel, entitled «Reikartz Carpathians» was openedinZhdeniyevo in Transcarpathia in December 2008. The resort was selected for the "debut" of the network Reikartz Hotels \& Resorts due to its location in one of the most picturesque regions. Currently the network includes 
17 hotels that are attracting its guests with high standards of quality and service.

3. Market of hotel services in Ukraine is now approaching saturation in the sector of five-and four-star hotels.

4. The formation of situation explained above leads to the gradual saturation of high-end hotel market as well as increase in the number of foreign companies in the market. As a result some companies have to work together and develop a common business strategy.

5. Sector of hotels of three stars and below remains unsaturated and represented mainly by the hotels with extremely low-maintenance and a small set of services.

6. There is no significant improvement in the activity level in the sector of hotel services in Ukraine, with Ukrainian companies delaying their market entrance. This can lead to the market being filled by the foreign hotel chains. At the same time western investors do not want to start their business in Ukraine without active presence of Ukrainian companies.

7. Due to the nature of specific markets it is impossible to provide adequate assessment of the situation in the industry. It is necessary to view different sectors of hotel services separately.

8. The problem of effective management remains important to national hotels. The shift from administrative methods of management to market methods was not easy and oftentimes managerial team that was supposed to maintain high levels of performance works on development. This shortcoming has also to deal with the founders/owners of the hotels. (Shumilova, 2005)

9. The issues related to the interaction with the government still remain problematic for the national hotel chains. The most notable issues are:

- Hotel project registration process;

- Allotment of land for construction;

- Passing the mandatory procedures in the fire and health departments;

- Obtaining the necessary permits and certificates.

10. The issue of standardization is also problematic because of inconsistencies between Ukrainian and European systems of standardization of hotel services. It is estimated that $80 \%$ of hospitality real estate including hotels, in need of repair and reconstruction.

These ambiguous situations complicate and slow down the activities of the companies in the hotel sphere. Yet, national hotel operators have an advantage being aware of existence of such matters and having knowledge of national legislation.

\section{Prospects of Development}

As for promising areas and market trends of hotel services in Ukraine, the gradual evolution is more logical option of the development and influence expansion for the existing companies. Example of tendency toward national companies' consolidation in the market of hotel services can be represented by the entrance of Kiev hotel market by the operator that owns 5-star Donbas Palace in the city of Donetsk. Prospective points:
1. For the first time in the history of Ukrainian hotel business hotel Donbas Palace was included in the association Leading-Hotels of the World. In November 2005, the hotel won a victory in the most prestigious competition in the tourism business which is World Travel Awards and was recognized as the Leading Hotel of Ukraine. The same hotel was awarded in 2008. Gorgeous, lush interior of Donbas Palace makes it a wonderful and hospitable place, created solely for the comfort and relaxation of its guests. Each of the 124 rooms of the hotel Donbas Palace was carefully designed to maximize space in the rooms. Staff wants to make guests feel comfortable and enjoy the comfort. Refined materials skillfully produced furniture and lamps were chosen to create absolute comfort for each room. The interiors are perfectly combined with modern technologies as for example floor heating in the bathrooms. Today the company is considering the construction of five-star hotels in major cities of Ukraine under the brand "DP" (Donbas Palace). Also, we cannot exclude the possibility of expanding the network of Donbas Palace beyond Ukraine.

2. It should be noted that the sector of hotels "deluxe" sets and defines the high dynamics of the industry in Ukraine. Increased attention of the hotel business to a higher category hotels is rooted in the fact that the previous government of Ukraine did not leave any hotels that could claim to be five star quality. Yet demand for luxury hotels grew due to the processes of redistribution of capital in the country and significant increase in the number of foreign tourists.

The most profitable segment of the market of luxurious hotels is close to saturation in the near future thus causing interest of many operators to market medium and small hotels with a moderate range of services provided.

3. The most adequate strategy of consolidation in the market of hotel services is based on the emergence of the hotels with 2-3 stars service levels. The targets of this business segment are representatives of domestic tourism. In the absence of the competition in this segment of the hotel industry the existing companies prefer to underestimate the needs of its customers and so provide services of lower quality.

4. Creation of a single hotel chain with universalservice and high level of services through the purchase and renovation of the existing hotel stock of small and medium categories can benefit not only the status of the national operator, but create benefits associated with the dominance in the market.

5. Regional Markets of hotel services in Ukraine are unsaturated, and have a slightly different performance demand. Higher category hotels are demanded in cities and resort centers. In most cities though, consumers prefer Midlevel hotels due to the income differences in the regions.

6. According to the analysts, in three to five years, foreign companies and international hotel operators will start offering their services for construction of various star hotels in major cities and resort areas of Ukraine. 
According to preliminary estimates of experts, and the fact that Ukraine's economy will grow steadily - at 5-7\% per year, the financial injection in the country's hotel industry could reach hundreds of millions of dollars.

7. According to experts from Radisson SAS Ukraine will soon need 40 different star hotels, including high quality 10-11 (four to five - in Kiev, four - in the coastal zone, and two-in Dnipropetrovsk). It is best, experts say, focusing on the reconstruction of already built and existing hotels, increasing their star. Especially that silent upgrade of Slavutych, Turyst and Bratyslava on the left bank of Dnipro River is carried using the funds accumulated by the same hotels.

8. The Austrian company "Warimpex AG" and multinational hotel corporation "Six continents" willing to invest 35 million dollars in the development of hotel business in Ukraine. The Government of Ukraine is also interested in wider attraction of foreign direct investments in the development of hotel business. The government is ready to amend the laws of Ukraine to improve the legal framework in the field of hospitality and tourism. The Government of Ukraine fights for the construction of hotels and roadside network of small hotels, which would provide comfort and tranquility to its customers.

9. There is annual investment of several hundred millions in the development of the hotel industry. To bring national tourism industry to the average (by European standards) level of comfort and quality of service vast cash inflows are necessary. Currently the Government of Ukraine together with company representatives is working to make hotel chain Marriot penetrate into the Ukrainian market of hotel services. It will attract a large number of American businessmen and tourists, who prefer only five star hotels in the big cities. The government is also negotiating with Baltic operator Rival Hotels to open the hotels of their chain in Ukraine. According to the department of tourism, two small luxury hotels with 100-150 rooms will soon emerge in Kyiv. Beginning and end terms of the construction has not yet been disclosed. The amounts of possible investments range from 40 to $45 \mathrm{mln}$. USD (Gorin, 2009).

According to the experts from tourism department, Ukraine urgently needs five or six middle-class hotels (two-and three-star), the cost of residence in which would not exceed 25-30 euro's per day. There is also a plan to create a network of youth hotels, and according to the National Tourist Administration, trust funds for their development should be provided from the budget of the country. Regarding comfortable hotel complexes, each city with a population of over a million people that expects substantial flows of foreign visitors must have at least a few four-star hotels. Based on the problems and prospects mentioned above there is urgency in Ukraine developing relevant priorities of the domestic hotel operator,

First, in the process of spreading its influence in a particular market, the company, a potential hotel operator can select construction projects or acquire existing hotels with subsequent reconstruction. The way to increase the staff of the national hotel operator will depend on the circumstances; sometimes the reconstructions of the hotel and retraining of staff can be more expensive and timeconsuming than the full-scale construction project.

Secondly, for possible national hotel operators fundamental question will be regarding gaining dominance in the regions, which gained its recognition by holding the World Cup in 2012.

There were some changes in the legislation on the hotel market of Ukraine. Thus, in August 2010 adopted a law "On amendments to some laws of Ukraine concerning the development and preparation of hotel infrastructure in Ukraine for the finals of the 2012 European Cup." According to this law hotels that were reconstructed, built and put into operation before September 1, 2012 are exempt from income tax for the next 10 years. Thanks to Euro 2012 53 facilities of the hotel industry were reconstructed and re-equipped in Lviv, the reconstruction was worth $2.2 \mathrm{bn}$. $\mathrm{UAH}$. The hotel infrastructure in the region increased by 1,000 modern rooms of high service levels. Four-star hotel Nobilis equipped with 49 rooms opened up in Lviv, the second phase is construction of hotel Leopolis (33 rooms), Vintag (17 rooms) and Shveytsarskyi (18 numbers). Sanatorium Kashtan was reconstructed into the 4-star hotel with 140 rooms, apartment complex Lisova Pisnia with 114 rooms and Royal Hotel with 137 rooms that meet the highest European standards were built in Truskavets city.

The number of foreigners who want to visit Kiev and Kharkiv increased, however the need to meet quality tourist services is not yet obtained. Among the economic and socio-political factors that hinder the development of tourism in Ukraine in general next aspects can be highlighted:

1) Insufficient development of tourism infrastructure, lack of tourist offices, indexes, travel guides and maps in foreign languages;

2) Lack of advertising of Ukraine abroad as a country interesting for tourists as well as individual advertising measures;

3) The decline in investment activity in 2014, caused by the unstable political and economic situation caused the clotting process in development plans in Ukraine. In general terms the crisis affected the performance and appearance of new projects.

In 2014 hotel market in Ukraine was in a critical situation. Customers number in the hotels in the capital has reached an absolute minimum $-28 \%$.

According to the company JLL, the number of hotels in Ukraine is growing, the market welcomes international companies, yet the returns on equity at these hotels remain low.

160 hotels with a total room availability equal to 11 thousand. Rooms, including nine hotels (just over 2.1 ths. Numbers) with brand names (Hyatt, InterContinental, Fairmont, two Radisson, Hilton, which opened in 2014, Holiday Inn, Ramada and Ibis) operate in Kyiv. Among the promising discoveries is hotel Park Inn (192 rooms), 
Aloft (310 rooms) and Renaissance (173 rooms), that are expected to open in 2015. There is also announcement of the opening of three hotels under the brand Ibis $(233,150$ and 233 numbers), one of which also includes 100 rooms under the brand Adagio.

Traditionally, most of demand for hotel services in Kyiv is formed by the business segment (about $80 \%$ of which come from abroad, the remaining $20 \%$ from the regions of Ukraine). Share of business tourists comprises $65-80 \%$ on average, while the rest is formed by representatives of the group and individual tourism.

Now we can say the hotel business is experiencing hard times. The acute political and economic crisis led to a decline in tourist flow both from abroad and inside the country. Hotel owners are forced to cut costs as it is almost impossible to impact the increase in the number of customers.

The first half of 2014 was characterized by the hotel real estate market marking antirecord: unstable economic situation, armed conflicts in Kiev and in the east, annexing the Crimean peninsula, undeveloped tourist infrastructure in the capital and in Ukraine in general led to a reduction in the number of tourists visiting Ukraine. From the beginning of year the number of hotel visitors travelling both from abroad and regions of the country significantly decreased.

Also, the low occupancy of hotels can be explained not only by the unstable situation in the country but by the fact that for several years in Ukraine market of shady services has been actively developing. The owners of apartments equip them for the reception of foreign tourists in the short term. Generally, private owners provide guests with a full range of additional services to ensure quests' transportation, interpreter (if necessary), meals and other services. With low fixed costs and, often without taxes payed, "shadow" businesses receive sufficient working capital to maintain service quality at a high level and expand business. Moreover shady hotel business has the flexibility to fluctuate prices depending on season and demand, since it is outside the scope of government regulations it does not face additional costs.

This year showed no improvement for the hotel market. Hoteliers say that during this season when there is highest business activity (February-March) all business events and conferences were virtually eliminated, which adversely affected the market of hotel services.

Speaking about the prospects of increasing the flow of tourists, they are still vague, as it will depend on the "speed" with which the political and economic situation in the country will stabilize.

Following the 1st quarter of 2014 market operators point to a very significant negative impact of political changes in the country and the current unstable state. Interest in Ukraine as a tourist country and a potential business partner is greatly reduced considering military action and danger to health and life. Thus, the occupancy rates of hotels in central Kyiv were about $20 \%$ (the normal index of 50\%). It is also worth noting that the number of trips, and accordingly tourists and businessmen not only from other countries but also within Ukraine decreased.
According to Colliers International, the average price of the room "at the front desk" at the end of March 2014 decreased compared to the same period last year (in euro): by $10 \%$ in the hotels $5^{*}$ and was $€ 365$, by $25 \%$ in the hotels of category $4 *$ and was $€ 133$, and by $20 \%$ in hotels category $3^{*}$ and was $€ 77$. However, the declared value of UAH equivalent increased by $130 \%$ in $5^{*}$ hotels and totaled $5500 \mathrm{UAH}$; by $110 \% 4^{*}-1990$ USD, and by $110 \%$ in $3^{*}-1150 \mathrm{UAH}$ (data UTG). Growth rates are usually offset by significant discount. Most of them are offered by the bookings of upper price segment and may be more than $50 \%$ of the requested amount at the front desk.

With the emergence of new quality hotels of upper price range (Hilton $\mathrm{H}$-Tower in Kiev put into operation in late March) competition in the segment $4 *-5$ among the capital's hotels intensified, which could lead to lower prices by $10-15 \%$.

It is hard to create accurate forecasts, given the political and economic situation in the country, but it is difficult to expect good results. It should be noted that majority of new deals in Kiev belong to the upper price and luxury segment, while the city needs more economic branded hotel segment. Scheduled openings are delayed, investors "took a break" and wait for the change in the situation.

In the current environment it is difficult to talk about the prospects for the hotel market and the investment appeal, but with the improvement in situation, investition interest will be directed to the same sectors as before the crisis.

Experts note that the most promising segment of the hotel market for Kyiv and Ukraine are quality $2 *-3 *$ hotel.

According to the company ArtBuild Hotel Group $(\mathrm{ABHG})$, the capital's hospitality sector still lags quantitative and qualitative characteristics of markets in Europe, Asia and North America. For example, there is 0.54 room rate availability for 1000 tourists in Kyiv. This figure is not only smaller than the rates of cities like Warsaw, Budapest, Prague, Berlin, Vienna, but not higher than rates in Lviv and Odessa.

To realize the touristic potential of Ukraine fully, the state and the government should:

- provide visitors a comfortable and safe environment for arrival in Ukraine;

- pursue effective policies of mass tourism, establish an appropriate concept;

- simplify and expedite visa obtaining process, abolish the visa regime for EU, USA, Canada, and Japan;

- reduce hotel fees;

- take measures to improve the condition of monuments and the creation of new facilities of mass tourism. Amend the laws on land use, change the rules for issuing relevant permits for the organizations related to the tourism industries to attract investments in opening new centers of recreation;

- create opportunities for the construction and operation of small motels and hotels of family type, which will provide more jobs for the population and can be a source of foreign exchange earnings.

This year the trend has improved slightly, the number of hotels in Eastern Europe is growing. By the end of 2015, 
only Ukraine, Poland and Russia plan to increase the number of hotel rooms by $18 \%$ each.

According to the report published by the Smith Travel Research, the three above-mentioned countries will increases the European hotel fund by 32700 rooms.

As of today, the biggest number of hotel rooms in Eastern Europe is in Russia, where there are 103000 rooms. Second is Bulgaria with 62000 hotel numbers and third is Czech Republic with 58000 rooms. Not far behind Poland, which as of June 2014 had 56000 hotel rooms.

By the end of 2015, Russia plans to increase its hotel fund by 5519 rooms, 4355 out of those were opened in 2014. Ukraine respectively, during this year hopes to open 1004 hotel rooms, Poland - 817 (Vahen, 2006).

Since 2008, Russia with its $4.8 \%$ annual rate remains a leader among the countries of Eastern Europe by growing dynamics of hotel stock. It should be noted that such development was stimulated by 2014 Winter Olympic Games held in Sochi.

Thirdly, with the target of market segment being defined, potential national hotel operator may inevitably encounter problems of brand recognition and effective management. With sufficient funding and understanding of the need to attract professionals, these issues should be addressed by the consulting companies. In the case of limited funding, the company will have to address these issues by the means of their own efforts, giving them priority status.

Fourth, to maximize its efficiency the national operator needs to base management system for the hotel business on the strategic vision and foresight. Based on this vision the policy of the company is being developed thus it represents the common goals and norms of relations and ensures viability and development structure.

Fifthly, to achieve the goals and objectives in the domestic hospitality industry, founders and owners of the company must first understand that their management should provide a clear organizational structure and the work within this structure should to be divided among all the employees on the basis of professionalism. It is also necessary to attract foreign professionals and companies to effectively transform the key functions of employees, to determine their accountability and whether there is appropriate effort from the staff and to establish strategy of network development (Lesnik, 2003).

\section{Conclusion}

To sum up, we can conclude that the emergence of new national hotel operator in Ukraine is not a utopia; moreover, such attempts are made today. In the sector of hotel services of the highest category national operators face harsh competition, not only based on price but also based on quality. To win such competition while maintaining individual brand is possible only by maintaining faultless management and marketing.

Emergence of national hotel operator is most likely to happen in the sector of middle-class hotel services because this segment is unsaturated and also very promising. Hotel facilities in this case will be based mainly in the regional centers and will be unionized by the single concept.

In any case, the development of Ukrainian hotel operators will mean a transition to a new level in the framework of the global market of hotel services. If before Ukraine was only described as undeveloped and unsaturated new market, the creation of a national network will create a new player in the global hotel market.

\section{References}

Biryukov, E. (2002) Tourism development in the world and its impact on the economy. Moscow, Economics, 168 p. Gorin, G. (2009) Features of the modern hotel industry of Ukraine Culture of Black Sea, № 171. - S. 117-120.

Vahen, L. (2006) Hospitality: Manual. - Rostov-on-Don: Phoenix, 416 p.

Shumilova, A. (2005) Hospitality Moscow, Publishing House of Literature in construction, 213 p.

Gulyaev, V. (2000) Organization of tourist activity: Textbook. Moscow, Nolydzh, 312 p.

Lesnik, A. (2003) The practice of marketing in hotel and restaurant business. Moscow: Infra, $488 \mathrm{p}$.

\section{Ирина АНТОНОВА}

\section{АНАЛИЗ РЫНКА ГОСТИНИЧНЫХ УСЛУГ В УКРАИНЕ}

Аннотация. Предметом исследования является рынок гостиничных услуг Украины за последние годы, ведь формирование рынка гостиничных услуг в Украине началось в первой половине 2000-х годов. Первоначально основное внимание, как местных, так и иностранных инвесторов было направлено на освоение гостиничного рынка Киева. Постепенно, с развитием гостиничного бизнеса Украины, интерес инвесторов начал смещаться и в сторону региональных городов, в первую очередь, крупных деловых центров страны (с населением около 1 млн. человек), таких как Харьков, Донецк, Днепропетровск, Запорожье, Львов и другие, а также курортных зон Украины - АР Крым, Карпаты, Одесса. По данным Всемирной туристической организации в течение последних 24 лет доход от международного туризма ежегодно растет на 9\%. Количество международных туристов ежегодно растет на 4\%. Значительно повлиял на активное развитие сегмента гостиничной недвижимости чемпионат Европы по футболу 2012 года, по требованиям организаторов которого города, которые проводили данный чемпионат (Киев, Харьков, Донецк, Львов), должны были обеспечить определенное количество гостиничных номеров разных категорий. 
Целью исследования является анализ проблем на рынке гостиничных услуг и перспективы их решения. Ведь индустрия гостеприимства в Украине, является одной из наиболее динамично развивающихся отраслей экономики. Приятно отметить, что во многих регионах открываются новые гостиницы, дома отдыха, санатории и пансионаты, реконструируются действующие, на качественно новый уровень выходит сервис, развивается инфраструктура. Ненасыщенные рынки гостиничных услуг разного уровня является прекрасной возможностью для гостиничных операторов уверенно войти на украинский рынок и проводить политику расширения своего влияния в отрасли. Поэтому данное исследование является весьма актуальным в настоящем.

Методологической базой исследования стали труды отечественных и зарубежных авторов, посвященных проблематике развития гостиничного хозяйства. На рынке гостиничных услуг есть определенные проблемы: 1. Тенденция заполнения отечественных рыночных ниш иностранными операторами.

2. На современном этапе экономического развития в Украине существует только два национальных гостиничных оператора - Premier Hotels and Resorts и Reikartz Hotels \& Resorts.

3. Украинский рынок гостиничных услуг сегодня близится к насыщению в секторе пяти- и четырехзвездочных отелей.

4. Создание объединения вышеуказанного типа объясняется постепенным насыщением рынка гостиниц высшего класса и приходом титулованных иностранных операторов, создало условия, в которых отдельные предприятия вынуждены сотрудничать и вырабатывать единую бизнес-стратегию.

5. Сектор гостиниц уровня трех звезд и ниже остается в Украине незаполненным и представлен в основном отелями с крайне низким уровнем обслуживания и небольшим набором услуг.

6. На сегодняшний день активизации деятельности в гостиничном секторе Украины почти не наблюдается, промедление национальных компаний может привести к наполнению рынка иностранными операторами. В свою очередь, западный инвестор не желает выходить на гостиничное поле Украины без активного присутствия там украинских компаний.

7. В силу специфики конкретных рынков невозможно дать однозначную оценку конъюнктуре в отрасли необходимо детализировать ситуацию в отдельных секторах гостиничных услуг.

8. Проблема эффективного менеджмента не нова для национальных гостиниц - переход от административных методов управления к рыночным оказался нелегким и чаще всего менеджмент, призванный обеспечивать качество обслуживания, занимается развитием. Этот недостаток присущ не только менеджменту, но касается и учредителей (собственников) гостиниц.

9. Непростыми для национальных гостиничных компаний остаются вопросы, связанные с взаимодействием с государственными структурами. Это и процесс регистрации гостиничного объекта, и отвод земельного участка под строительство, прохождение обязательных процедур в ведомствах пожарной охраны и санэпидемиологического контроля, получения необходимых разрешений и сертификатов.

10. Вопросы стандартизации услуг также проблематично вследствие несоответствия украинской и европейской систем стандартизации предоставления гостиничных услуг. По предварительным оценкам, 80\% туристической инфраструктуры, включая отели, требуют ремонта и переоборудования.

Такие неоднозначные ситуации усложняют и замедляют деятельность предприятия гостиничной сферы, однако именно здесь национальные гостиничные операторы могут реализовать преимущество осведомленности в подобных вопросах и знания особенностей национального законодательства.

Результаты. Но, несмотря на сложные политические и экономические условия появление нового национального гостиничного оператора в Украине - не утопия, более того, подобные попытки предпринимаются уже сегодня. В секторе гостиничных услуг высшей категории национальному оператору придется столкнуться с жесткой конкуренцией, причем не, только ценовой, но и конкуренцией качества услуг. Выиграть такое соперничество, сохраняя индивидуальную марку, можно только при условии безошибочного менеджмента и маркетинга. В секторе гостиничных услуг среднего класса появление национального гостиничного оператора наиболее вероятно, поскольку этот сегмент ненасыщенный и одновременно достаточно перспективный. Гостиничные объекты в таком случае будут располагаться, преимущественно, в регионах и объединены единой концепцией. В любом случае развитие украинских гостиничных операторов будет означать переход на принципиально новый уровень в рамках участия на мировом рынке гостиничных услуг - если раньше Украина представляла собой только новые емкие рынки, то создание национальной сети может обозначить нового равноправного участника рынка гостиничных услуг. 